\title{
Penerapan K-Nearest Neighbour Dalam Penerimaan Peserta Didik Dengan Sistem Zonasi
}

\author{
Denni Kurniawan, Ade Saputra* \\ Magister Ilmu Komputer Universitas Budi Luhur \\ Naskah Diterima : 22 Oktober 2019; Diterima Publikasi : 8 November 2019
}

DOI : 10.21456/vol9iss2pp212-219

\begin{abstract}
Admission of new students is a routine activity at the beginning of each new meeting year in all formal educational institutions. At the moment the acceptance of new students uses the zoning system and has been regulated by Permendikbud No. 20 in 2019. This zoning system will accept students where their residence enters through the user area with the school environment. With this Permendikbud the government hopes that there will be an evenness in the quality of education in all schools, so that schools will no longer get the title of superior and non-superior schools. But in a system, the zoning improves anxieties in the school environment. This research supports to help the participating school students will be accepted in accordance with the provisions of the Ministry of Education and Culture. In overcoming problems that arise in the school environment there needs to be a system that can overcome that problem. In this study using the K-Nearest Neighbor (K-NN) method. Where the K-NN method will do the classification of new learners' residence with the school. In determining the classification using the K-NN method used for zoning and non-zoning areas, it is seen based on the closest $\mathrm{K}$ value. In finding the optimal value in this study using the Rapidminer application. The optimal high-level test results at K 5 where the value of this $\mathrm{K}$ is $83.36 \%$.
\end{abstract}

Keywords : Data Mining; K-NN; Rapidminer; Zonasi

\begin{abstract}
Abstrak
Penerimaan peserta didik baru merupakan kegiatan rutinitas di setiap awal tahun ajaran baru di semua Lembaga Pendidikan formal. Saat ini penerimaan Peserta didik baru menggunakan sistem zonasi dan sudah diatur oleh Permendikbud No. 20 tahun 2019. Sistem zonasi ini akan menerima peserta didik dimana tempat tinggalnya masuk kedalam area terdekat dengan lingkungan sekolah. Dengan Permendikbud tersebut pemerintah mengharapkan adannya kerataan mutu pendidikan disemua sekolah, sehingga sekolah tidak lagi mendapatkan predikat sekolah unggulan dan sekolah non unggulan. Tetapi pada kenyataannya sistem zonasi tersebut mengalami suatu keresahan di lingkungan sekolah. Penelitian ini bertujuan untuk membantu pihak sekolah dalam menetapkan peserta didik yang akan diterima sesuai dengan ketetapan dari Permendikbud. Dalam mengatasi permasalahan yang timbul di lingkungan sekolah perlu adanya suatu sistem yang dapat menangani permasalahan itu. Pada penelitian ini menggunakan metode K-Nearest Neighbour (K-NN). Dimana metode K-NN ini akan melakukan pengklasifikasian terhadap tempat tinggal peserta didik baru dengan sekolah. Dalam menentukan klasifikasi dengan metode K-NN yang digunakan untuk wilayah zonasi dan non zonasi dilihat berdasarkan nilai K terdekat. Dalam mencari nilai akurasi optimal pada penelitian ini menggunakan aplikasi Rapidminer. Hasil pengujian tingkat akurasi yang optimal terdapat pada K 5 dimana Nilai dari K tersebut bernilai 83,36\%.
\end{abstract}

Kata kunci : Data Mining; K-NN; Rapidminer; Zonasi

\section{Pendahuluan}

Sekolah merupakan salah satu lembaga pendidikan yang sangat penting untuk membangkitkan potensi yang ada dalam diri manusia itu sendiri. Selain itu, sekolah dapat mempersiapkan manusia dalam menghadapi masa depan agar hidup mereka dapat lebih sejahtera, baik secara individu maupun dalam bermasyarakat, berbangsa dan bernegara (Umaedi et al., 2016). Untuk membangkitkan potensi dari peserta didik akan memilih sekolah yang sesuai dengan bakat dan

\footnotetext{
*) Penulis korespondensi: 234tkj@gmail.com
}

minatnya. Penerimaan peserta didik baru merupakan suatu agenda rutinitas yang dilakukan oleh lembaga pendidikan nasional disemua jenjang. Untuk memilih sekolah yang menjadi minat dari peserta didik baru adalah mereka akan mencari sekolah yang dianggap sekolah favorit. Sehingga sekolah yang tidak memiliki predikat tidak favorit akan mengalami kesulitan dalam mendapatkan peserta didik. Hal inilah yang membuat Menteri Pendidikan dan Kebudayaan Muhajir Effendy membuat suatu peraturan Penerimaan Peserta Didik Baru (PPDB) dengan sistem zonasi dengan Permendikbud No. 51 
Tahun 2018 tentang penerimaan peserta didik baru pada Taman Kanak-Kanak, Sekolah Dasar, Sekolah Menengah Pertama, Sekolah Menengah Atas dan Sekolah Menengah Kejuruan. Pada Permendikbud No. 51 Pasal 20 ayat (1) telah dijelaskan. Penetapan zonasi dilakukan pada setiap jenjang oleh Pemerintah Daerah sesuai dengan kewenangannya, dengan prinsip mendekatkan domisili peserta didik dengan Sekolah (Mendikbud, 2018). Tujuan dari Permendikbud No. 51 tersebut merupakan strategi pemerintah dalam menyeratakan mutu dalam pendidikan. Sehingga tidak ada lagi kesan antara sekolah favorit dengan sekolah tidak favorit. Tetapi pada kenyataannya sistem zonasi ini menimbulkan banyak permasalahan mengingat jarak antara sekolah satu dengan sekolah yang lainnya berjauhan, sehingga para peserta didik baru akan mengelami kesulitan mengingat jarak antara sekolah dengan tempat tinggalnya berjauhan dan jumlah kuota siswa baru yang telah disediakan pihak sekolah melebihi dari jumlah peserta didik yang mendaftar.

Penelitian yang pernah dilakukan (Kartika et al., 2017) yang berjudul Penentuan Siswa Berprestasi Menggunakan Metode K-Nearest Neighbor dan Weighted Product (Studi Kasus SMP Negeri 3 Mejayan), Permasalahan pada penelitian ini belum seimbangnya dalam melakukan penilaian dikarenakan nilai akademik masih menjadi pertimbangan yang utama dibandingkan nilai nonakademik. Nilai non akademik hanya dijadikan data penunjang yang tidak jelas dalam pembobotan nilai. Sehingga dirasa kurang adil dalam penentuan siswa berprestasi. Pengujian perangkingan pertama memiliki tingkat akurasi $66.67 \%$. Pengujian perangkingan kedua memiliki tingkat akurasi sebesar $88.89 \%$. Pengujian perangkingan ketiga memiliki tingkat akurasi sebesar $100 \%$. Dengan nilai rapor, ektrakulikuler, kepribadian, dan kedisplinan menjadi prioritas utama dalam penentuan siswa berprestasi. Pada penelitian lainnya yang dilakukan (Sumarlin, 2015) dengan judul Implementasi Algoritma $K$ Nearest Neighbor Sebagai Pendukung Keputusan Klasifikasi Penerima Beasiswa PPA dan BBM. Penelitian ini membahas tentang klasifikasi beasiswa peningkatan prestasi akademik (PPA) dan bantuan belajar mahasiswa (BBM) berdasarkan variabelvariabel yang telah ditentukan dengan menerapkan algoritma $K$-Nearest Neighbor. Hasil klasifikasi dari sistem ini akan digunakan sebagai keputusan dalam pemberian beasiswa bagi mahasiswa yang mengajukannya. Hasil testing untuk mengukur performa algoritma K-Nearest Neighbor menggunakan metode cross validation, Confusion Matrix dan kurva Receiver Operating Characteristic (ROC), akurasi yang diperoleh untuk beasiswa peningkatan prestasi akademik mencapai $88,33 \%$ dengan nilai Area Under Curva (AUC) 0,925 dari 227 record dataset, sedangkan akurasi yang diperoleh untuk beasiswa bantuan belajar mahasiswa mencapai
90\% dengan nilai AUC 0,937 dari 183 record dataset, akurasi yang diperoleh untuk gabuangan beasiswa peningkatan prestasi akademik dan bantuan belajar mahasiswa mencapai $85,56 \%$ dan nilai AUC 0,958.

Dari beberapa penelitian yang telah dilakukan sebelumnya akan dijadikan acuan atau pedoman dalam penelitian ini. Adapun yang menjadi pembeda dari penelitian ini dengan penelitan sebelumnya adalah dari segi atribut yang digunakan. Pada penelitian ini menggunakan dua atribut yaitu latitude dan longitude. Atribut latitude diambil dari garis lintang dimana garis tersebut diambil dari titik tempat tinggal peserta didik, sedangkan atribut longitude diambil garis bujur tempat tinggal peserta didik itu.

Penelitian ini bertujuan untuk mempermudah kinerja dari Panitia Penerimaan Peserta Didik Baru (PPDB) didalam mengklasifikasi calon peserta didik baru yang akan diterima sesuai dengan wilayah zonasi.

\section{Kerangka Teori}

\subsection{Data Mining}

Data mining adalah proses yang menggunakan Teknik statistik, matematika, kecerdasan buatan dan machine learning untuk mengekstraksi dan mengidentifikasi informasi yang bermanfaat dan pengetahuan yang terkait dari berbagai database besar. Data mining merupakan salah satu cabang ilmu komputer yang relative baru (Novita, 2016). Secara umum semua operasi dalam data mining dapat dikelompokkan menjadi dua metode yaitu metode deskriptif dan metode prediktif. Metode deskriptif bertujuan untuk menemukan pola, relasi, atau anomaly dalam data yang mudah dipahami oleh manusia. (Adinugroho dan Sari 2018). Teknik dalam data mining dibagi menjadi beberapa bagian kelompok diantaranya, (Kartika et al., 2017) (Adinugroho dan Sari 2018), teknik Classification ini akan membentuk suatu klasifikasi yang data baru dengan memanipulasi data yang sudah ada. Proses pengelompokkan menggunakan acuan data yang telah diketahui kelompok atau kelasnya. Data yang belum memiliki kelompok dapat ditentukan kelompoknya melalui proses pembandingan dengan data yang sudah diketahui sebelumnya. Algoritma klasifikasi yang umum digunakan meliputi : Decision Tree, Nä̈ve Bayes, K-Nearest Neighbor, jaringan saraf tiruan dan Support Vector Machine. Teknik dalam data mining selanjutnya adalah Association ini digunakan untuk mengenali kelakuan dari kejadiankejadian khusus atau proses dimana hubungan asosiasi muncul pada setiap kejadian. Association merupakan metode pencarian pola relasi antar data dalam sebuah kumpulan data. Berdasarkan pola tersebut kemunculan suatu data dapat diprediksi berdasarkan kemunculan data lainnya. Algoritma ini meliputi Apriori, Eclat, FP-growth. Teknik yang paling sering digunakan dalam data mining adalah 
Clustering yang digunakan untuk menganalisa pengelompokkan berbeda terhadap data, clustering ini mirip dengan klasifikasi, namun pengelompokkan belum didefinisikan sebelum dijalankannya tool data mining. Biasanya menggunakan metode Neural Network atau statistik. Pengelompokkan data pada clustering berlangsung otonom dengan cara membandingkan semua data yang belum memiliki kelas dan membaginya kedalam beberapa kelas berdasarkan kemiripan antar data. Algoritma clustering meliputi: K-Means, Fuzzy C-Means, Hierarchical clustering, Gaussian Mixtures. Tugas dari klasifikasi adalah memprediksi keluaran variabel/class yang bernilai kategorikal atau polynomial (Saifudin, 2018). Proses klasifikasi didasarkan pada empat komponen diantaranya (Sumarlin, 2015) :

1. Kelas Variabel dependen yang berupa kategorikal yang merepresentasikan 'label' yang terdapat pada objek. Contohnya: resiko penyakit jantung, resiko kredit, customer loyalty, jenis gempa.

2. Predictor Variabel independen yang direpresentasikan oleh karakteristik (atribut) data. Contohnya: merokok, minum alkohol, tekanan darah, tabungan, aset, gaji.

3. Training dataset Satu set data yang berisi nilai dari kedua komponen di atas yang digunakan untuk menentukan kelas yang cocok berdasarkan predictor.

4. Testing dataset Berisi data baru yang akan diklasifikasikan oleh model yang telah dibuat dan akurasi klasifikasi dievaluas.

\subsection{Algoritma $K$-Nearest Neighbor (K-NN)}

Secara umum data mining memiliki teknik-teknik yang digunakan dalam melakukan pengklasifikasian. Pendekatan dari teknik-teknik itu terdiri dari 2 teknik, yaitu teknik Supervised learning dan unsupervised learning. Supervised learning adalah sebuah pendekatan dimana Algoritma K-Nearest Neighbor merupakan suatu metode yang menggunakan algoritma supervised. Perbedaan antara supervised learning dengan unsupervised learning adalah pada supervised learning bertujuan untuk menemukan pola baru dalam data dengan menghubungkan pola data yang sudah ada dengan data yang baru. Sedangkan pada unsupervised learning data belum memiliki pola apapun, dan tujuan unsupervised learning untuk menemukan pola dalam sebuah data. Dalam penelitian penerimaan peserta didik baru ini menggunakan algoritma supervised learning. Metode K-Nearest Neighbor bekerja berdasarkan asumsi bahwa suatu data akan memiliki kelas atau kategori yang sama dengan data yang berada disekitarnya. Konsep ini dikenal dengan konsep ketetanggaan (Adinugroho dan Sari, 2018). Menurut Gorunescu (Badu, 2016), K-Nearest Neighbor merupakan sebuah metode untuk melakukan klasifikasi terhadap objek baru berdasarkan (K) tertangga terdekat. Untuk mendukung pengambilan keputusan tersebut, akan terlihat mayoritas dari keputusan teman atau tetangga. Teman atau tetangga tersebut dapat dipilih berdasarkan dengan kedekatannya. Dekat atau jauhnya tetangga biasanya dihitung berdasarkan Euclidean Distance, atau dapat juga menggunakan rumus jarak yang lain. Dimana hasil dari sampel uji yang baru diklasifikasikan berdasarkan mayoritas dari kategori K-Nearest Neighbor. Dengan demikian K-Nearest Neighbor dari sebuah instance $x$ didefinisikan sebagai $K$ instance yang memiliki jarak terkecil (kedekatan terbesar, nearest) dengan x. Dekat atau jauhnya tetangga biasanya dihitung berdasarkan Euclidean Distance yang direpresentasikan pada persamaan 1 sebagai berikut (Kartika et al., 2017):

$D(a, b)=\sqrt{\sum_{k=1}^{d}\left(a_{k}-b_{k}\right)^{2}}$

dimana matriks D (a,b) adalah jarak skalar dari kedua vector a dan b dari matriks. Dalam menentukan nilai K sebaiknya dilihat dari jumlah klasifikasi bila jumlahnya genap maka sebaiknya menggunakan nilai $\mathrm{K}$ yang ganjil, dan sebaliknya jika jumlah klasifikasi jumlahnya ganjil maka sebaiknya dalam menggunakan nilai $\mathrm{K}$ yang genap, karena jika tidak begitu maka sistem kemungkinan tidak akan mendapatkan jawaban. Berikut ini adalah proses dari metode K-Nearest Neighbor yang ditunjukkan pada Gambar 1 (Noviansyah et al., 2018) :

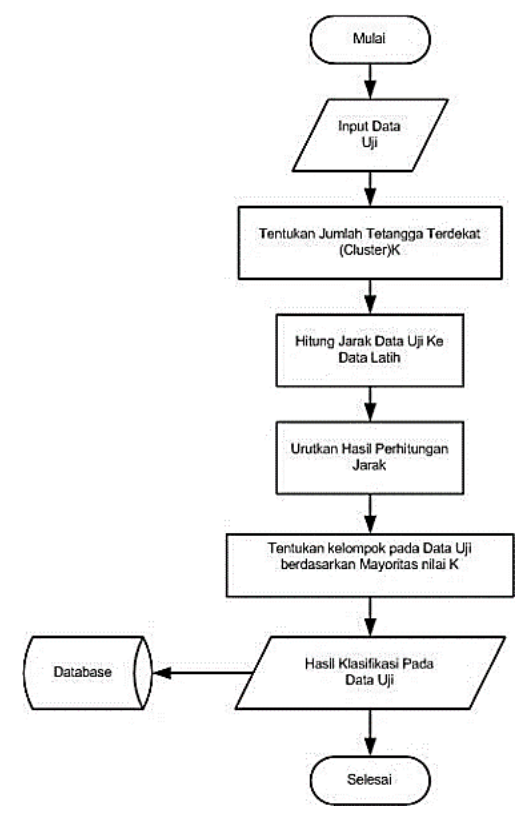

Gambar 1. Proses Metode K-Nearest Neighbor

\subsection{RapidMiner}

RapidMiner adalah sebuah solusi untuk melakukan analisis terhadap data mining, text mining dan analisis prediksi. RapidMiner memiliki sifat yang open source serta digunakan untuk berbagai teknik 
yang bersifat deskriptif dan prediksi dalam membuat suatu keputusan (Aprillia et al., 2013). Dalam penelitian ini menggunakan confussion matrix sebagai alat ukur performa algoritma klasifikasi. Confussion matrix atau matrik kebingungan merupakan sebuah perhitungan yang membandingkan dataset dengan hasil klasifikasi sesuai dengan data sebenarnya dengan jumlah keseluruhan data. Hasil akhir dari matrik ini adalah tingkat akurasi dengan satuan persen (\%). Tingkat akurasi ini yang nantinya dijadikan acuan para peneliti terkait performa algoritma klasifikasi tersebut (Hasanah et al., 2019). Berikut ini adalah model dari Confussion matrix yang terlihat pada tabel 1 dibawah ini (Hasanah et al., 2019) :

Tabel 1. Model Confussion matrix

\begin{tabular}{lll}
\hline Correct & \multicolumn{2}{l}{ Classified as } \\
Clasification & + & \\
\hline+ & True positive & False negatives \\
& (A) & (B) \\
- & False positives & True negatives \\
& (C) & (D) \\
\hline
\end{tabular}

Adapun rumus yang digunakan dalam model Confussion matrix adalah (Hasanah et al., 2019) :

Akurasi $=(\mathrm{A}+\mathrm{D}) /(\mathrm{A}+\mathrm{B}+\mathrm{C}+\mathrm{D})$

Hasil perhitungan tersebut dapat dijadikan nilai akurasi yang optimal untuk digunakan.

\section{Metode}

Model Perancangan Sistem Pada penelitian ini menggunakan pendekatan Systems Development Life Cycle (SDLC) yang digunakan dalam pengembangan perangkat lunak. Metodologi untuk Pengembangan System merupakan proses standard yang digunakan tim pengembang untuk menghubungkan semua langkah yang diperlukan untuk menganalisa, merancang, mengimplementasi, dan memelihara Sistem informasi (Inggi et al., 2018). Dalam pengembangan framework dibutuhkan beberapa tahapan yang ada pada SDLC yaitu planning, analysis, design, implementation, dan maintenance seperti pada gambar berikut ini:(Inggi et al., 2018).

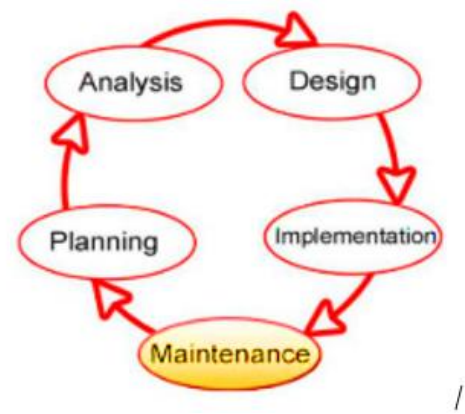

Gambar 2. Tahapan SDLC
Tahapan pada Gambar 2 dapat dijelaskan sebagai berikut:

a) Planning atau tahap perencanaan bertujuan untuk mengidentifikasi dan memprioritaskan sistem apa saja yang akan dikembangkan, dan sasaransasaran yang ingin dicapai.

b) Analysis atau tahap analisis sistem merupakan tahap penelitian atas system yang telah ada dengan tujuan untuk merancang sistem baru atau memperbaharui sistem yang sudah ada.

c) Design atau tahap perancangan sistem merupakan tahap untuk menetukan proses tahapan atau teknik untuk menerapkan sistem baru atau sistem yang dikembangkan dari sistem sebelumnya..

d) Implementation atau tahap implentasi sistem merupakan tahap untuk mengimplementasikan rancangan dari tahap-tahap sistem yang dibangun atau dikembangkan serta melakukan uji coba terhadap sistem tersebut.

e) Maintenance atau tahap pemeliharaan sistem merupakan proses pemeliharaan sistem selama penggunaan agar tetap mampu beroperasi secara benar

Siklus SDLC dijalankan secara berurutan, mulai dari langkah pertama hingga langkah keenam. Setiap langkah yang telah selesai harus dikaji ulang, kadangkadang bersama expert user, terutama dalam langkah spesifikasi kebutuhan dan perancangan sistem untuk memastikan bahwa langkah telah dikerjakan dengan benar dan sesuai harapan. Jika tidak maka langkah tersebut perlu diulangi lagi atau kembali ke langkah sebelumnya (Inggi et al., 2018).

\section{Hasil dan Pembahasan}

\subsection{Analisis Metode K Nearest Neighbor}

Proses perhitungan dengan metode $K$-Nearest Neighbor ini dilakukan untuk memperoleh label dari sistem zonasi berdasarkan kriteria-kriteria yang digunakan untuk penerimaan siswa baru berdasarkan zonasi. Jumlah data yang digunakan pada penelitian ini sebanyak 50 data yang terdiri dari data training dan data testing. Data training merupakan data yang diambil dari data peserta didik baru di SMKN 5 Kota Tangerang tahun ajaran 2018/2019. Data training dari penelitian ini sebanyak 35 data dari peserta didik baru di tahun itu. dimana data tersebut terdapat 18 data training zonasi dan 17 data training non zonasi. Atribut yang digunakan dalam data training ini adalah atribut Latitude dan longitude, atribut ini dipilih berdasarkan titik lokasi atau tempat tinggal dari peserta didik. Untuk data training dapat dilihat pada Tabel 2 berikut ini: 
Tabel 2. Data Training

\begin{tabular}{|c|c|c|c|c|}
\hline No & Nama & Latitude & Longitude & Klasifikasi \\
\hline 1 & 0001-0683 & -6.217964 & 106.689143 & zonasi \\
\hline 2 & 0002-0683 & -6.188698 & 106.673039 & zonasi \\
\hline 3 & $0003-0683$ & -6.224478 & 106.689594 & zonasi \\
\hline 4 & 0004-0683 & -6.196643 & 106.678416 & zonasi \\
\hline 5 & 0005-0683 & -6.164766 & 106.595306 & zonasi \\
\hline 6 & 0006-0683 & -6.266679 & 106.597233 & zonasi \\
\hline 7 & 0054-0683 & -6.180875 & 106.620347 & non zonasi \\
\hline 8 & $0055-0683$ & -6.153566 & 106.577946 & non zonasi \\
\hline 9 & $0056-0683$ & -6.2405 & 106.669329 & non zonasi \\
\hline 10 & $0057-0683$ & -6.237395 & 106.65981 & non zonasi \\
\hline 11 & $0058-0683$ & -6.243802 & 106.691642 & non zonasi \\
\hline 12 & $0012-0683$ & -6.215279 & 106.647383 & zonasi \\
\hline 13 & $0013-0683$ & -6.186139 & 106.660354 & zonasi \\
\hline 14 & 0014-0683 & -6.164599 & 106.676606 & zonasi \\
\hline 15 & $0015-0683$ & -6.284518 & 106.762555 & zonasi \\
\hline 16 & 0016-0683 & -6.222399 & 106.698367 & zonasi \\
\hline 17 & $0017-0683$ & -6.176125 & 106.640527 & zonasi \\
\hline 18 & 0018-0683 & -6.199004 & 106.652896 & zonasi \\
\hline 19 & 0081-0683 & -6.241366 & 106.645128 & non zonasi \\
\hline 20 & $0082-0683$ & -6.236462 & 106.655592 & non zonasi \\
\hline 21 & 0083-0683 & -6.204738 & 106.638855 & non zonasi \\
\hline 22 & 0084-0683 & -6.185393 & 106.646851 & non zonasi \\
\hline 23 & $0085-0683$ & -6.183004 & 106.681631 & non zonasi \\
\hline 24 & $0086-0683$ & -6.184342 & 106.693005 & non zonasi \\
\hline 25 & $0034-0683$ & -6.210392 & 106.659624 & zonasi \\
\hline 26 & $0035-0683$ & -6.212079 & 106.688969 & zonasi \\
\hline 27 & $0036-0683$ & -6.221551 & 106.692330 & zonasi \\
\hline 28 & $0037-0683$ & -6.216907 & 106.682250 & zonasi \\
\hline 29 & $0038-0683$ & -6.212079 & 106.688969 & zonasi \\
\hline 30 & $0092-0683$ & -6.22871 & 106.707249 & non zonasi \\
\hline 31 & 0093-0683 & -6.221767 & 106.713783 & non zonasi \\
\hline 32 & 0094-0683 & -6.228821 & 106.715094 & non zonasi \\
\hline 33 & 0095-0683 & -6.220075 & 106.698915 & non zonasi \\
\hline 34 & 0096-0683 & -6.228839 & 106.704024 & non zonasi \\
\hline 35 & 0097-0683 & -6.232508 & 106.688134 & non zonasi \\
\hline
\end{tabular}

Sedangkan sampel dari data testing yang digunakan sebanyak 15 data dari peserta didik baru di SMKN 5 Kota Tangerang ditahun ajaran 2019/2020. Atribut yang digunakan pada data testing ini juga sama dengan atribut yang digunakan pada data training yaitu latitude dan longitude, data testing tersebut dapat dilihat pada Tabel 3 di bawah ini.

Tabel 3. Data Testing

\begin{tabular}{lccc}
\hline No & Nama & Latitude & Longitude \\
\hline 1 & 100311120 & -6.196706 & 106.662312 \\
2 & 100721165 & -6.195319 & 106.664415 \\
3 & 100421103 & -6.194487 & 106.656325 \\
4 & 100411154 & -6.204599 & 106.650446 \\
5 & 100111138 & -6.207628 & 106.645768 \\
6 & 100511131 & -6.210828 & 106.656819 \\
7 & 100811206 & -6.214220 & 106.642914 \\
8 & 100410986 & -6.215020 & 106.645285 \\
9 & 100410801 & -6.220235 & 106.657655 \\
10 & 100610972 & -6.223829 & 106.660971 \\
11 & 100610821 & -6.223947 & 106.666281 \\
12 & 100110895 & -6.225845 & 106.672665 \\
13 & 100110983 & -6.231466 & 106.675283 \\
14 & 101010911 & -6.235881 & 106.681731 \\
15 & 100510820 & -6.235124 & 106.684123 \\
\hline
\end{tabular}

Pada tabel 3 telah diketahui letak latitude dan longitude dari peserta didik baru yang diukur berdasarkan tempat tinggal dari peserta didik baru. Pada langkah awal adalah dengan menentukan nilai $\mathrm{K}$ yang terbaik. $\mathrm{K}$ disini dimaksudkan sebagai titik dari objek yang akan diukur. Misalnya telah ditentukan 5 tetangga terdekat $(\mathrm{K}=5)$, berarti titik objek yang akan diambil sebanyak 5 titik objek. Setelah ditentukan nilai K maka langkah selanjutnya adalah dengan menghitung kuadrat jarak eucliden objek terhadap data training yang diberikan dengan menggunakan rumus (1), sedangkan Tabel 4 merupakan hasil K 5 terhadap jarak eucliden.

Tabel 4. Hasil K 5 terhadap jarak eucliden

\begin{tabular}{clll}
\hline NO & No Peserta & Euclidean Distance & Klasifikasi \\
\hline 1 & 100311120 & 0.034231639 & zonasi \\
& & 0.013386433 & zonasi \\
& & 0.016104123 & zonasi \\
& & 0.023829213 & zonasi \\
& & 0.010746872 & zonasi \\
2 & \multirow{2}{*}{100721165} & 0.010872489 & zonasi \\
& & 0.014063462 & zonasi \\
& & 0.026239105 & zonasi \\
& & 0.010038133 & zonasi \\
& & 0.03305055 & zonasi \\
3 & 100421103 & 0.017688141 & zonasi \\
\hline
\end{tabular}




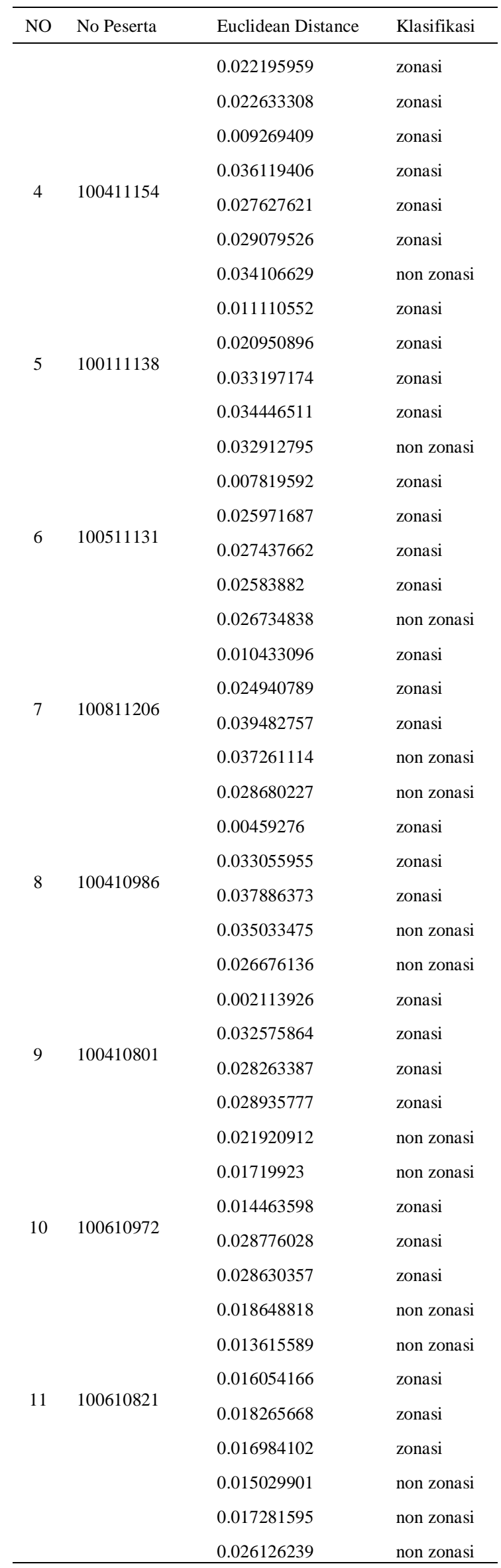

\begin{tabular}{|c|c|c|c|}
\hline $\mathrm{NO}$ & No Peserta & Euclidean Distance & Klasifikasi \\
\hline \multirow[t]{5}{*}{12} & 100110895 & 0.019349512 & zonasi \\
\hline & & 0.015925981 & zonasi \\
\hline & & 0.010819578 & non zonasi \\
\hline & & 0.016570056 & non zonasi \\
\hline & & 0.02048887 & non zonasi \\
\hline \multirow{5}{*}{13} & 100110983 & 0.019389601 & zonasi \\
\hline & & 0.01385118 & zonasi \\
\hline & & 0.013234227 & non zonasi \\
\hline & & 0.021973221 & non zonasi \\
\hline & & 0.012687402 & non zonasi \\
\hline \multirow{5}{*}{14} & 101010911 & 0.017879206 & zonasi \\
\hline & & 0.011969509 & zonasi \\
\hline & & 0.015740515 & non zonasi \\
\hline & & 0.024418833 & non zonasi \\
\hline & & 0.011482293 & non zonasi \\
\hline \multirow{5}{*}{15} & 100510820 & 106.7734218 & zonasi \\
\hline & & 106.7812781 & zonasi \\
\hline & & 106.7993521 & non zonasi \\
\hline & & 106.7554446 & non zonasi \\
\hline & & 106.8283389 & zonasi \\
\hline
\end{tabular}

Pada tabel 4 merupakan hasil perhitungan dari jarak eucliden objek data testing terhadap data training. Bila dari 5 tetangga terdekat terdapat 3 label yang termasuk ke dalam wilayah zonasi maka dapat disimpulkan bahwa data yang dicari itu termasuk ke dalam wilayah zonasi. Sebaliknya, jika dari 5 tetangga tersebut terdapat 2 label yang termasuk ke dalam wilayah zonasi maka dapat disimpulkan bahwa data yang dicari itu termasuk ke dalam wilayah non zonasi. Hasil dari klasifikasi dengan nilai K 5 dapat dilihat pada tabel 5 dibawah ini.

Tabel 5. Hasil klasifikasi dari K5

\begin{tabular}{cll}
\hline No & No. Peserta & Klasifikasi \\
\hline 1 & 100311120 & Zonasi \\
2 & 100721165 & Zonasi \\
3 & 100421103 & Zonasi \\
4 & 100411154 & Zonasi \\
5 & 100111138 & Zonasi \\
6 & 100511131 & Zonasi \\
7 & 100811206 & Zonasi \\
8 & 100410986 & Non Zonasi \\
9 & 100410801 & Non Zonasi \\
10 & 100610972 & Non Zonasi \\
11 & 100610821 & Zonasi \\
12 & 100110895 & Zonasi \\
13 & 100110983 & Non Zonasi \\
14 & 101010911 & Non Zonasi \\
15 & 100510820 & Zonasi \\
\hline
\end{tabular}




\subsection{Penentuan Nilai Akurasi}

Pada pengujian akurasi nilai K pada penelitian ini menggunakan aplikasi Rapid Miner versi 5.2. Dengan aplikasi tersebut akan menentukan nilai akurasi yang optimal untuk digunakan dalam memilih nilai $\mathrm{K}$ terdekat. Hasil akurasi nilai $\mathrm{K}$ dengan menggunakan rapid miner dapat dilihat pada gambar 3 berikut ini.

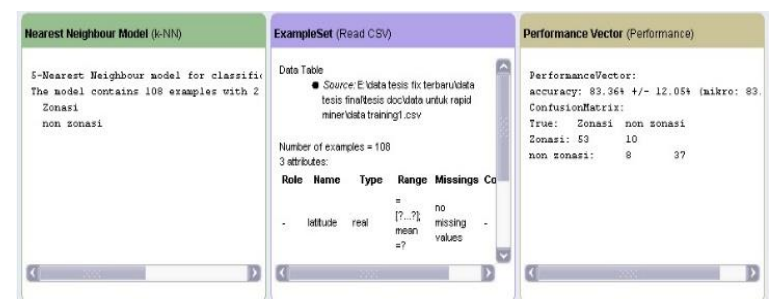

Gambar 3. Pengujian akurasi nilai K

Pada gambar 3 menunjukkan tingkat akurasi dari K5. Adapun kesimpulan dari nilai akurasi yang optimal untuk digunakan dapat dilihat pada Tabel 6 dibawah ini:

Tabel 6. Perbandingan jumlah cluster dan akurasi

\begin{tabular}{cc}
\hline Cluster & Akurasi \\
\hline K 1 & $78,73 \%$ \\
K 2 & $79,64 \%$ \\
K 3 & $80,55 \%$ \\
K 4 & $77,82 \%$ \\
K 5 & $83,36 \%$ \\
K 6 & $81,55 \%$ \\
K & $82,45 \%$ \\
K 8 & $80,55 \%$ \\
K & $82,45 \%$ \\
K 10 & $77,00 \%$ \\
\hline
\end{tabular}

Dari tabel 6 hasil pengukuran nilai akurasi dengan bantuan aplikasi rapidminer yang memiliki nilai persentase paling tinggi berada pada K5 dengan nilai akurasi sebesar $83,36 \%$.

\subsection{Evaluasi Confussion matrix}

Perhitungan menggunakan confussion matrix untuk menentukan prosentase data yang sesuai dengan kenyataan dibandingkan jumlah keseluruhan data yang ada. Untuk perhitungan menggunakan model Confussion matrix dapat dilihat pada tabel 7 dibawah ini :

Tabel 7 Perhitungan Confussion matrix

\begin{tabular}{llll}
\hline Correct & Classified as & & \\
Clasification & Zonasi & & Non Zonasi \\
\hline Zonasi & 53 & 10 & \\
Non Zonasi & 8 & 37 & \\
\hline
\end{tabular}

Perhitungan akurasi pada tabel 7 dapat menggunakan rumus (2) dengan hasil akurasi sebesar $83,33 \%$.

\section{Kesimpulan}

Setelah melakukan analisa penelitian ini, maka dapat disimpulkan bahwa pada penerapan metode $K$ Nearest Neighbor (K-NN) yang digunakan telah mampu digunakan sebagai acuan dalam menentukan peserta didik yang diterima berdasarkan zonasi dan non zonasi sehingga dapat membantu pihak sekolah khususnya panitia penerimaan peserta didik dalam mengklasifikasi calon siswa untuk menentukan wilayah zonasi dan non zonasi. Dari percobaan perhitungan penentuan penerimaan peserta didik baru menggunakan perhitungan model Confussion matrix dan Rapidminer, Nilai akurasi yang diusulkan terletak pada K5 dengan tingkat akurasi sebesar 83,36\%.

\section{Ucapan Terima Kasih}

Peneliti mengucapkan banyak terima kasih kepada semua pihak yang telah membantu peneliti hingga penyusunan dalam terbitan jurnal.

\section{Daftar Pustaka}

Adinugroho, S. dan Y.A. Sari., 2018. Implementasi Data Mining Menggunakan WEKA. 1st ed. Malang: UB Press.

Aprillia, Dennis, D.A. Baskoro, Lia, A. dan I.W.S. Wicaksana. 2013. Belajar Data Mining dengan RapidMiner. Jakarta: Remi Sanjaya.

Badu, Z.S., 2016. Penerapan Algoritma K-Nearest Neighbor Untuk Klasifikasi Dana Desa." (November).

Hasanah, Riyan, L., Hasan, M. dan Pangesti, W.E., 2019. Klasifikasi penerimaan dana bantuan desa menggunakan metode K-NN (K-Nearest Neighbor). TECHNO Nusa Mandiri 16(1):1-6.

Inggi, Rahmat, Sugiantoro, B. dan Prayudi, Y., 2018. Penerapan system development life cycle (SDLC) dalam mengembangkan framework audio forensik. SemanTIK 4(2):201-36.

Kartika, Irjaya, J., Santoso, E. dan Sutrisno, 2017. Penentuan siswa berprestasi menggunakan metode K-Nearest Neighbor dan Weighted Product (Studi Kasus : SMP Negeri 3 Mejayan)." $1(5)$.

Mendikbud, 2018. Peraturan Menteri Pendidikan Dan Kebudayaan Republik Indonesia No 51 Tahun 2018." Retrieved June 12, 2019 (https://jdih.kemdikbud.go.id/arsip/PERMENDI KBUD NOMOR 51 TAHUN 2018.pdf).

Noviansyah, Reza, M., Rismawan, T. dan Midyanti, D.M., 2018. Penerapan data mining menggunakan metode k-nearest neighbor untuk klasifikasi indeks cuaca kebakaran berdasarkan data AWS (Automatic Weather Station) Studi Kasus: Kabupaten Kubu Raya. Jurnal Coding, Sistem Komputer Untan, 06(2):48-56. 
Novita, R., 2016. Teknik Data Mining: Algoritma C 4.5. 1-12.

Saifudin, A., 2018. Metode data mining untuk seleksi calon mahasiswa pada penerimaan mahasiswa baru di Universitas Pamulang. Jurnal Teknologi 10(1):25-36.
Sumarlin, S., 2015. Implementasi algoritma k-nearest neighbor sebagai pendukung keputusan klasifikasi penerima beasiswa PPA dan BBM. Jurnal Sistem Informasi Bisnis 5(1):52-62.

Umaedi, H. dan Siswantari, 2016. Manajemen Berbasis Sekolah. Edisi 1. edited by D. Setiawan and A. Suroso. Tangerang Selatan: Universitas Terbuka. 